\title{
Study on Reduction or Exemption of Individual Income Tax for the Chinese Oceangoing Seafarers
}

\author{
Peng Yu ${ }^{1}$, Wang Deling ${ }^{2, *}$ \\ ${ }^{1}$ School of Law, Shanghai Maritime University, Shanghai, China \\ ${ }^{2}$ Merchant Marine College, Shanghai Maritime University, Shanghai, China \\ Email address: \\ ypeng@shmtu.edu.cn (Peng Yu), dlwang@shmtu.edu.cn (Wang Deling) \\ ${ }^{*}$ Corresponding author
}

To cite this article:

Peng Yu, Wang Deling. Study on Reduction or Exemption of Individual Income Tax for the Chinese Oceangoing Seafarers. International Journal of Law and Society. Vol. 3, No. 4, 2020, pp. 195-203. doi: 10.11648/j.ijls.20200304.16

Received: November 12, 2020; Accepted: November 24, 2020; Published: December 4, 2020

\begin{abstract}
The reduction and exemption of the oceangoing seafarers' individual tax can not only improve the seafarers' professional happiness and the attractiveness of being a seafarer, but also effectively increase the labor supply of seafarers and help to promote the implementation of the Maritime Power Strategy. Recently, the State Council announced the individual tax reduction policy for oceangoing seafarers in China. However, there is still a gap between this policy and the prevailing practices of major international shipping nations, which are mainly manifested in three aspects: the temporary nature of the policy, insufficient tax relief, and not adapting to seafarer occupational characteristics. In view of the difficulty and complexity of reducing and exempting seafarers' personal tax directly through domestic legislation, a new and feasible scheme is put forward according to Article 4, Item 9 of the Personal Tax Law: to promote the revision of MLC 2006, so as to definitize that the provisions concerning the individual tax reduction and exemption of seafarers are involved and help our seafarers enjoy the preferential policy of individual tax reduction and exemption in essence. At the same time, concrete procedures and specific contents of the proposal are analyzed in the scheme. Finally, the feasibility of amending MLC 2006, is predicted in the scheme. Since the scheme is in line with the legislative concept of MLC 2006, of "Equal Pay for Equal Work" and to improve seafarers' income with little impact on China's overall tax revenue, the study indicates that the amendment shall be supported by the contracting states, shipowner as well as seafarer groups. To sum up, the tax reduction and exemption scheme is reasonable and feasible.
\end{abstract}

Keywords: Chinese Oceangoing Seafarers, Individual Income Tax, Reduction or Exemption,

Chinese Individual Income Tax Law, Maritime Power, MLC 2006

\section{Introduction}

In the Report of the 19th National Congress of the Communist Party of China, Xi, J. P. [1] demanded that "China should adhere to the overall planning of land and sea and speed up building of a maritime power", which once again sounded the clarion calling for the construction of a maritime power. A hundred year's plan, it's all about talent. The Ministry of Transport of PRC promulgated the Chinese Crew Development Plan (2016-2020) [2] in September 2016. The Ministry of Transport of PRC [3] pointed out that the crew, as the pioneer in ocean development and water transportation, playing an important role in building a maritime power, promoting the "One Belt And One Road", serving the Yangtze River economic belt and promoting the development of water transportation.

The Seventh Amended Amendment to the Individual Tax Law (draft) was reviewed again at the Fifth Session of the 13th NPC Standing Committee on August 27, 2018, has entered into force from January 1, 2019. This amendment deletes the insufficient preferential policies on seafarers' individual income tax in the existing Individual Income Tax Law (hereinafter referred to as "Individual Tax Law"). This revision is inconsistent with the common practice of other major maritime powers and difficult to attract and regulate the development of Chinese seafarers. Fortunately, on November 20,2019 , the executive meeting of the state council decided 
that from January 1, 2019 to the end of 2023, the wages and salaries of ocean-going seafarers who have sailed on ships for more than 183 days a year will be reduced by $50 \%$ and included in the taxable income amount. However, the policy has some shortcomings such as temporary and insufficient relief. More importantly, the policy of tax reduction for seafarers does not meet the requirements of seafarers' professional characteristics.

Standing at the new historical point, the questions directly related to the development of seafarers must be answered. How does the existing seafarers' personal tax exemption policy meet the seafarers' development needs? Is there any other feasible way to reduce seafarers' personal income tax after the temporary policy expires? What are the common policies of major shipping countries? As a result, it is of great theoretical and practical value to study the Chinese seafarer's individual tax payment and the way of reducing and exempting it, which involves the strategy of being a maritime power and human resource construction. This paper studies the current status of Chinese seafarers' individual income tax payment and the necessity of reduction or exemption of individual income tax, combined with the analysis of seafarers' individual income tax policies in major maritime countries, and proposes a new feasible path for Chinese seafarers' reductions and exemptions, avoiding the shortcomings of the current policy of reducing personal taxes for ocean-going seafarers.

\section{Analysis on the Necessity of Chinese Oceangoing Seafarers' Individual Income Tax Deduction}

A hundred year's plan, it's all about talent. The seafarer team is an important guarantee for the sustainable development of the maritime industry, as well as the basic strength of building of a maritime power and the first resource of strategic significance. Without a stable team of seafarers and the services and contribution of the vast majority of seafarers, it is impossible to speak of enforcing the strategy of "ocean power" and creating the "21st Century Maritime Silk Road".

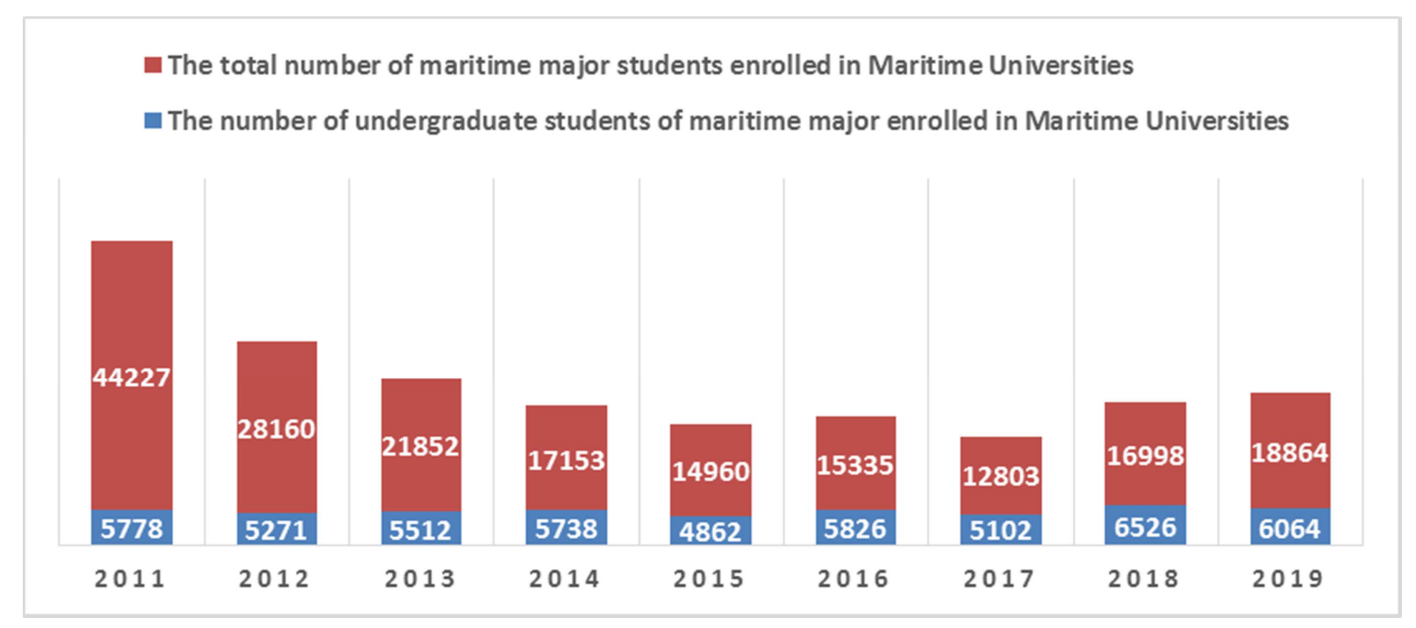

Figure 1. Changes in enrolment number of maritime majors among 2011-2019 [4-11].

With the development of our society and economy, there are more and more occupations for people to choose. The career of being oceangoing seafarers is not well recognized due to its non-fixed working time, danger of living and working place, long-term closure of living and working environment, strong labor mobility and instability [12]. In recent years, the seafarers' occupational income is no longer superior to the land and shore occupational income, and even tends the phenomenon of inversion. Vocational attraction has further declined, the phenomenon of "abandoning ship and going ashore" has gradually increased, and the number of students graduated from maritime colleges and universities has dropped significantly and the willingness of maritime graduates to work on board has also gradually weakened. In the long run, if effective measures are not taken, Chinese seafarers will face a lack of successors and the implementation of national maritime strategy will also be affected.

Under the leadership of the Maritime Safety Administration of PRC, Wang et al [13] proceed to a comprehensive and thorough study of the current status and development of the Chinese crew. The project investigated graduates from 19 maritime colleges in Liaoning, Hebei, Henan, Shandong, Jiangsu, Shanghai, Zhejiang, Jiangxi, Hubei, Fujian, Guangdong and other provinces. The analysis found that "salary income" and "employer satisfaction" are in positive correlation. In the survey of "career choice factor", salary became the most significant factor among the $36 \%$ of undergraduate graduates and $51 \%$ vocational college graduates. Research group also proceeded to investigate China Shipping International Ship Management Co., Ltd.(now COSCO Shipping seafarer Management Co., Ltd.), as well as Shanghai Ocean Shipping Co., Ltd. and Shanghai Huayang Maritime Tech Co., Ltd. The survey showed that there are about $10 \%$ of the crews moving every year, and the 5 -year turnover rate is as high as 55\%. Among them, "salary income" is the most important consideration for outgoing seafarers.

At this point, whether there is a causation between the tax relief and the increase in labor supply, as a theoretical question, 
needs to be answered. Ye et al [14] answered the question well. The article, which used CHFS's balanced plane statistics in 2011 and 2013, demonstrated and estimated the impact of the 2011 income tax reform on the labor participation rate and working hours of laborers in China relied on DID and FE. The research indicated that the tax reform in 2011 generally increased the labor participation rate of Chinese residents by $5.8 \%$ and as for the labor who had already entered in labor market, there were no plant increase in labor hours. Further research shows that the greater the tax reduction, the stronger the stimulating on labor participation. Every $1 \%$ tax reduction can increase the labor participation rate by $0.9 \%$, and the tax reduction per 100 yuan can increase the labor participation rate by $0.08 \%$. Compared with the male, the female labor supply elasticity world be more affected by tax reform. On the contrary, the male were more sensitive to tax reduction. At the same time, In order to exclude the incomparability of different income groups and enhance the identification, the article refers to the idea of the breakpoint regression method and selects the sample of 800 yuan income range and 1000 yuan income range on both sides of the tax rate boundary to exclude the labor supply effect of this tax reform to get consistent results. The tax reform in 2011 on individual tax reductions improved Chinese overall labor supply.

MA [15] analysed, in order to encourage the development of the medical industry, it can deduct up to $30 \%$ of income in other industries in the personal income tax cost deduction project, but for the medical industry it can deduct to $60 \%$ of income which can encourage people to engage in the medical industry.

On account of continuous downturn in shipping industry, shipping companies have suffered long-term losses, and even have bankruptcy liquidation. The situation that the above-mentioned seafarers 'salary does not match seafarers' expectations and pay-outs is difficult to change in the short time. Socialism with Chinese characteristics has entered a new era, and China's development is in a new historical location. In the era of implementing the "Belt and Road "initiative, opening wider to the outside world, and building a community with a shared future for mankind, it is only possible through the support of special policies to keep within limit of the loss of seafarers' talents, maintain the stable development of the seafarers' team, and guarantee the implementation of national ocean strategy. Throughout the world's major shipping countries, the reduction of seafarers 'personal income tax can not only increase the income of seafarers, but also effectively improve the happiness and attraction of seafarers' career. It is a more effective and feasible policy. Therefore, it's essential to study deeply the current status of Chinese seafarers 'personal income tax payment, find gaps with internationally practices, and propose a set of feasible practices for the reduction of Chinese seafarers' personal taxes.

\section{The Status Quo of Individual Income Tax Paid by Chinese Seafarers}

Any tax has income and adjustment function, which are of mutual interdependence. Compared with the value-added tax, the adjustment function of individual income tax ranks number one and the income function follow closely [16].

China enacted the Individual Tax Law in 1980, marking the establishment of China's Individual Income Tax System. The Individual Tax Law has undergone six revisions to date. And the Individual Tax System has gone through the initial development stage (1978-1993) of parallelly internal and external tax systems, the unified and preliminary development stage (1994-2004) and the enhanced Legalization stage of individual tax (from 2005) [17].

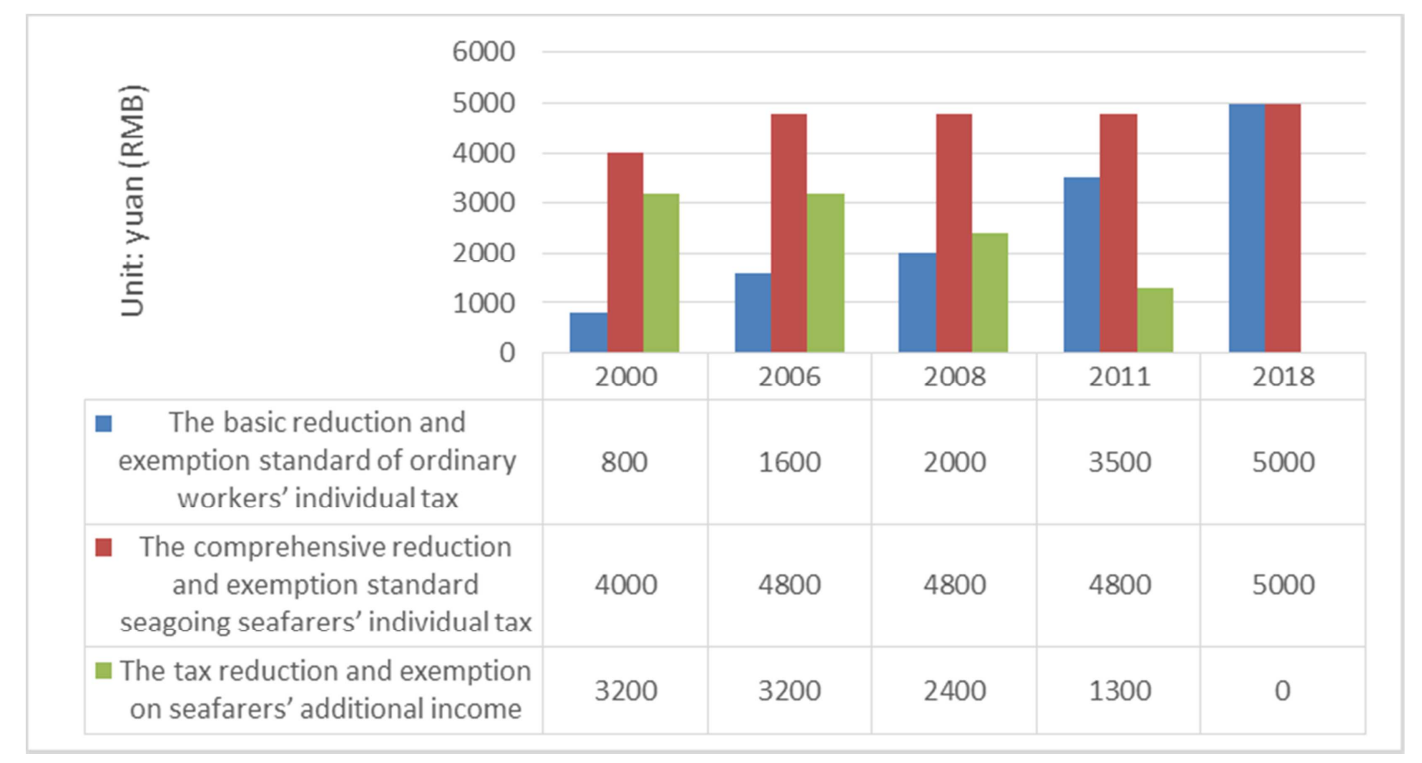

Figure 2. Comparison of individual tax reduction and exemption standards between oceangoing seafarers and ordinary workers.

The preferential tax policy for oceangoing seafarers in China is mainly reflected in the way of levying and enabling seafarers to enjoy the additional reduction and exemption provided in the tax law. The basic standard of individual 
income tax reduction and exemption for ordinary workers rose from $800 \mathrm{CNY}$ in 1980 to 3,500 CNY to date under Individual Tax Law (2011). By contrast, seafarers' additional reduction and exemption decreased from 3,200 CNY to 1,300 CNY, and the standard for the seafarers combined income tax reduction and exemption has increased from 4,000 CNY in 2000 to $4,800 \mathrm{CNY}$ in 2006 while remained unchanged for 12 years.

In addition to the two traditional amendments, namely raising the basic reduction and exemption standard for comprehensive income, optimizing and adjusting the tax rate structure, the Seventh Amendment of the Individual Tax Law set up a special additional reduction and exemption, which reflects the difference of individual burden and is more in line with the basic principle of Individual Income Tax and conducive to the fairness of the tax system. However, to this day, when the strategy of becoming maritime power was put forward for the first time in the report at 18th Party Congress and the explicit target of "speeding up the construction of a Maritime power" raised in the report at 19th Party Congress", the Amendment of Individual Income Tax Law removed the special additional reduction and exemption expenses (1300 $\mathrm{CNY} /$ month) instead, making oceangoing seafarers in line with the 60000 yuan/year tax reduction and exemption of the basic standards as ordinary workers. The re-existing insufficient seafarer individual duty privilege policy is no longer in existence.

The main contents of personal income tax reform in 2018 include the adjustment of tax rate bracket, adjustment of exemption amount and increase of special additional deductions. Wang $\mathrm{Yu}$ and others wrote "Study on Income Redistribution Effect of Individual Income Tax Reform in 2018" [18]. In this paper, authors used the CHIP data to study the income redistribution effect of the personal income tax reform in 2018. The results show that the adjustment of tax rate bracket, the adjustment of exemption amount and the increase of special additional deduction all worsen the income distribution among Chinese residents.

According to Article 4, section 10 in China Individual Tax Law, "other tax-exempt income prescribed by the State Council" can be used as the basis for exemption of personal income tax. On November 20, 2019, the Executive Council of the State Council made a decision on seafarers' tax reduction. This policy responded to the concerns of the shipping industry and the representatives of the National People's Congress and CPPCC members on the reduction of personal income tax for seafarers recently. However, as a temporary policy, the policy still has a gap with the prevailing practices of major international shipping countries. Firstly, the policy is temporary rather than permanent. Secondly, the policy is a reduction of seafarers' personal tax rather than an exemption; Thirdly, the policy applies to the "applicable to ocean-going crew members sailing for more than 183 days a year". The aforesaid "one year" refers to a tax year in China, which is from January 1 to December 31. The seafarer's time on board is not fixed, and there are a large number of seafarers boarding for 6 to 8 months in the second half of the year. At the same time, in view of strong liquidity, seafarers may work for two shipping companies during a year. The calculation of individual tax reduction conditions is not continuous. If strictly pursuant to the tax reduction policy to enforce, for seafarers who board the ship in the second half of the year and work for two different shipping companies, the income for the first two years will not get a discount in tax reduction.

\section{Analysis of Individual Tax Policy for Seafarers in Major Maritime Powers}

It is studied that there are always individual tax reduction and exemption policies for seafarers according to the tax laws and regulations of the world's major maritime powers or regions. On the basis of the degree of reduction and exemption, the policies are listed below: complete exemption from the individual income tax of seafarers' total income, conditional exemption from individual income tax of seafarers' total income, conditional exemption from individual income tax seafarers' offshore income, making preferential individual income tax policies for seafarers (including directly reducing or exempting the total amount of individual income tax inside the company, setting higher standard than general tax threshold, providing tax subsidies under certain conditions, adopting excess progressive of tax rate) etc.

Table 1. Summary of individual tax policy for seafarers in major maritime powers.

\begin{tabular}{|c|c|c|}
\hline Preferential policy category & Country & \\
\hline $\begin{array}{l}\text { Totally exemption from seafarers' personal } \\
\text { income tax }\end{array}$ & Singapore, Philippines, Denmark. & \\
\hline \multirow{2}{*}{$\begin{array}{l}\text { Conditional exemption from personal income } \\
\text { tax for all seafarers' income } \\
\text { Conditional exemption from seafarers' personal } \\
\text { income tax on marine revenue }\end{array}$} & $\begin{array}{l}\text { Conditions: provided that the sailing time } \\
\text { reaches XX days. }\end{array}$ & $\begin{array}{l}\text { The United Kingdom ( } 183 \text { days), Australia ( } 90 \text { days), } \\
\text { France ( } 183 \text { days), South Africa ( } 183 \text { days) }\end{array}$ \\
\hline & India, Japan. & \\
\hline \multirow{5}{*}{ Formulation of preferential tax policies } & Direct tax reduction and exemption & Netherlands ( $38 \%$ of shipping companies' tax exempted) \\
\hline & & Ireland (international voyage 161 days, 6350 Pounds) \\
\hline & Tax subsidy & Finland ( $48 \%$ or 18000 Euros) \\
\hline & & Norway ( $30 \%$ or 80 thousand kronor or 198000 Kroner) \\
\hline & Low tax rate & Greece (Senior seafarers $3 \%$, ordinary seafarers $1 \%$ ) \\
\hline
\end{tabular}

The above preferential policies not only make seafarers in these countries enjoy more sense of professional honor, but also reduce the cost of shipping enterprises and promote the sustainable and healthy development of shipping industry as 
well as enhance its international competitiveness. Seemingly, these policies are tax preference given in consideration of the particularity of seafarer. However, on a deeper level, these preferential policies are subsidies and supports for key human resources of the countries to maintain the status of maritime powers and develop maritime strategies.

It is worth noting that the vast majority of countries or regions that have reduced or exempted individual tax on ocean-going seafarers are clearly stipulated in the "Tax Law" of that country or region, and almost no administrative regulations or orders are implemented. This guarantees both the stability of the policy and the authority of the policy. In addition to the principle of "broad tax base, less preferential treatment, low tax rate and strict tax collection and management", the choice of the path of China's personal tax reform should take into account the competitiveness of China's tax in the international community, view problems from the perspective of development, actively deal with the tax system reform of other countries, and maintain China's tax international competitive advantage [19].

\section{Analysis of the Follow-up Way of Tax Reduction and Exemption for Chinese Oceangoing Seafarers}

Based on the foregoing analysis, the current seafarers 'individual tax reduction policy does not fully adapt to the occupational characteristics of seafarers' unfixed time and mobility. Reducing and exempting corporate operating tax and seafarers' personal tax has become a common practice in the international shipping industry, but various sectors have different opinions on this in China. Due to the shortage of domestic legislative resources, the lack of due attention to seafarers and the small size of seafarers, it is difficult to include the issue of seafarers' individual income tax exemption into the legislative plan of the National People's Congress. The existing seafarers' personal tax reduction is valid from January 1, 2019 to the end of 2023. It is not known how the seafarers' tax will be paid after 2023. This article proposes a completely new feasible path, through the amendment of the Maritime Labor Convention 2006 (hereinafter referred to as "MLC 2006,") to fully exempt the seafarers from tax. This avoids situations where existing policies may not adapt to the occupational characteristics of seafarers. It not only made the preferential policies for Chinese seafarers 'personal taxes consistent with internationally accepted practices, but also avoided falling into disputes in various circles in China, and maintained the stability and authority of the seafarers' personal tax reduction and exemption policies.

\subsection{Reduction and Exemption of Chinese Seafarers' Individual Tax Through Amendments of International Conventions}

Article 4, paragraph 9, of the Individual Tax Law clearly stipulates that "income exempted from tax as stipulated in international conventions and agreements signed by the Chinese government shall be exempt from individual income tax". On November 12, 2016, MLC 2006, came into force in China. The ratification of this convention exerts a profound impact on the protection of the rights and interests of Chinese seafarers. As a result, it provides a new feasible way for Chinese seafarers' individual income tax reduction exemption: promoting the amendment of $M L C 2006$, ,, making it clear that the provisions relating to the seafarers' individual income tax reduction and exemption are included, and then applying the provisions of article 4, paragraph 9 of the individual tax law, so that Chinese seafarers can enjoy the preferential benefit of the personal income tax reduction and exemption.

\subsection{Specific Way of Amending MLC 2006}

MLC 2006, is composed of preface and text. The main body consists of "Articles", "Regulations" and "Codes". The "Articles" stipulate the core principles of the convention, the fundamental rights of seafarers and the basic obligations of the member states of the convention [20]. The "Regulations" stipulate general provisions on the working and living conditions of seafarers and the obligations of member states. The "Codes", on the other hand, stipulate the detailed implementation of the "Regulations", which is composed of a mandatory "Standard A" and a non-mandatory "Guideline B".

The "Codes" are divided in accordance with the above means for two reasons. On the one hand, it is to ensure the convention to be adopted and come into force. On the other hand, when it comes to some contents such as wage standard, seafarers recruiting agencies and seafarers' social security, etc in $M L C$ 2006. It is difficult to form a global standard. Provided that the global standard is formed, this standard may only reflects nominal fairness lacking practical maneuverability given the great disparity in world's economic development today. For that reason, "Guideline B" is not enforceable. The contracting states can carry out flexible domestic legislation in accordance with their domestic situations, which will greatly enhance the maneuverability of the convention. Meanwhile, $M L C$ 2006, has established a mechanism that can continuously and effectively update the contents of this convention with the development of world economy and shipping technology, thus ensuring the lasting vitality of $M L C$ 2006, to some extent.

MLC 2006, contains two amendment adoption procedures, namely article 14 and 15 of the convention. The procedure for amending the convention, as provided for in Article 14 of the convention, is essentially the procedure for the adoption of the convention by the International Labour Organization, which is relatively more difficult. The procedure for amending the code, as provided for in Article 15 of the convention can be interpreted as "a simplified procedure for updating the convention", which is established to meet the technical part of the convention without having to amend the convention as a whole.

Detailed comparison between Article 14 and 15 in $M L C$ 2006 , in terms of procedural requirements for the adoption effectiveness of amendments are given in Table 2 . 
Table 2. Comparison between the fourteenth amendment procedure and the fifteenth amendment procedure.

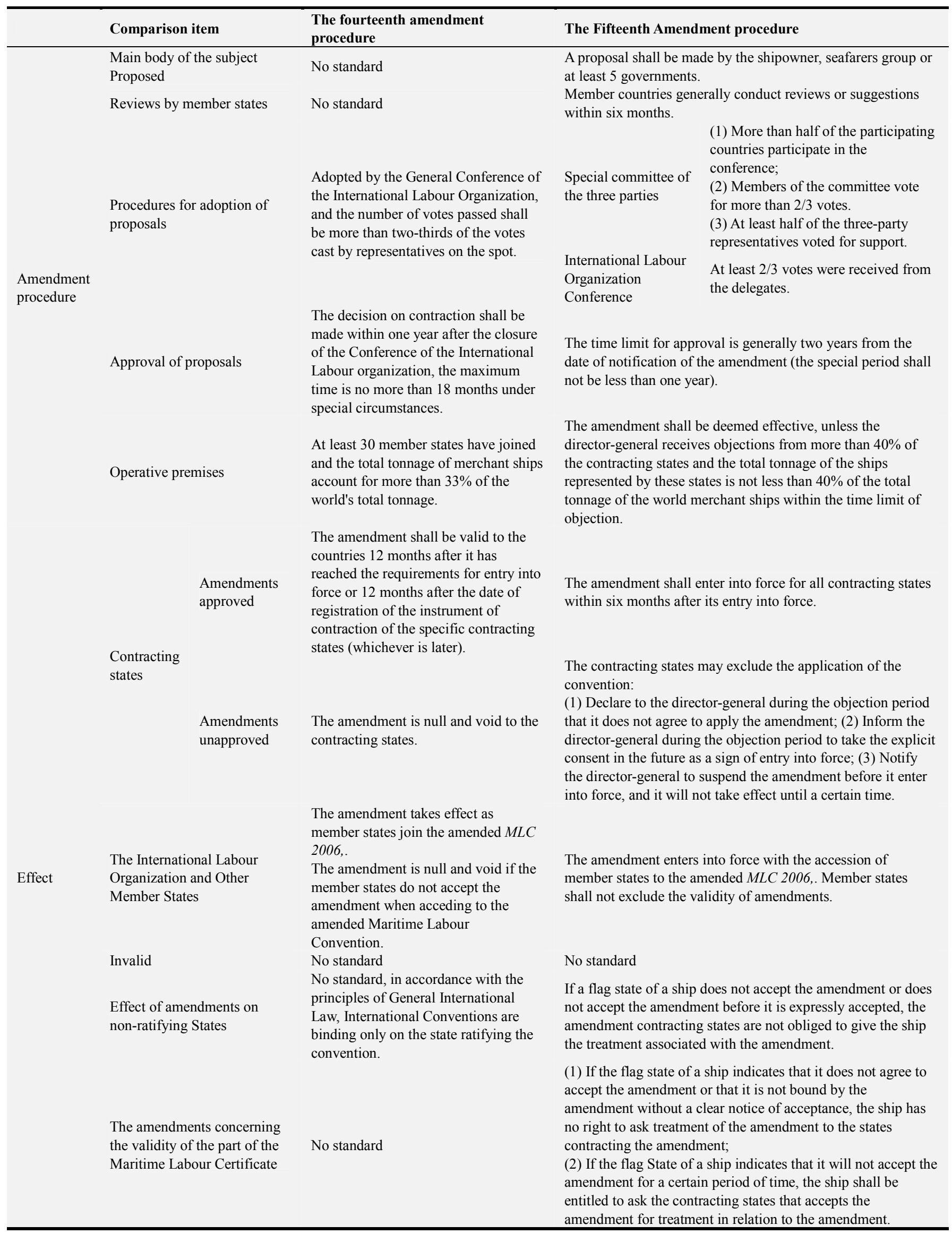


The analysis of table 2 shows that the amendment procedure of article 15 is easier to achieve in promoting the entry into force of the amendment and its application. Of the above two amendment procedures, the amendment to the "Codes" through article 15 of the amendment procedure to make the MLC 2006, provision on seafarer income tax reduction and exemption is a more feasible scheme.

\subsection{Specific Contents of Proposal of MLC 2006, Amendment}

In consideration of that the "Wage Standard A2.2" is an inductive description, details shall not be contained. Considering that the seafarers' income stipulated in the Collective Seafarers' Agreement of Seafarers accounts for the vast majority of the seafarers' total income, and the seafarer' income tax in most of the major maritime powers support the direct exemption or conditional reduction and exemption of seafarer income tax in domestic legislation. It is suggested that following terms should be added between paragraphs 5 and 6 in the "Standard A2.2":

"The Contracting States shall ensure that the individual income tax on remuneration stipulated in collective agreements is reduced or exempted for seafarers."

Accordingly, in "B2.2 Wages Guideline", guidance is provided to the contracting states on how to reduce and exempt the personal income tax on seafarers. At present, the major maritime powers mainly adopt such measures: complete exemption from the individual income tax of seafarers' total income, conditional exemption from individual income tax of seafarers' total income, conditional exemption from individual income tax seafarers' offshore income. Hence, the following new clauses shall be added in the Guideline.

"Guideline B2.2.4- reduce and exempt seafarers' personal income tax"

The reduction or exemption of personal income tax on remuneration stipulated in the Collective Agreement of Seafarers shall be realized by one of the following ways:

Full exemption from personal income tax on seafarers' total income;

Completely exempt from personal income tax on the total income of seafarers or the remuneration stipulated in collective agreements, provided that certain conditions are met, such as working on ships sailing internationally for a specified number of days."

\section{Feasible Expectation of Amending MLC 2006}

Although an amendment adopted in accordance with amendment procedure of Article 15 is more likely to be approved and come into effect, the procedure has not been simplified. The Amendment adoption procedure by the Special Committee of Three Parties in the amendment procedure of Article 15 is increased on the basis of amendment procedure of Article 14. As can be seen from table 2, Higher requirements are needed in the number of votes, proportion of members present and the proportion of three parties in the amendment adoption procedure by the Special Committee of Three Parties. To amend MLC 2006, and add the terms of the seafarers' tax reduction and exemption, the support from contracting states and the organization shipowner and the seafarer is indispensable. In the meantime, the amendment must conform to the legislative concept $M L C$ 2006.

\subsection{The Prediction of the Countries Concerned Supporting the Amendment}

As mentioned above, the major maritime powers have enacted domestic laws to reduce and exempt the personal income tax of seafarers to varying degrees and the major maritime powers are also $M L C 2006$, contractors. As a result, if the provisions of the $M L C 2006$, on the reduction and exemption of individual income tax for seafarers are involved, it's much more likely to obtain support from the major maritime powers.

\subsection{The Prediction of the Shipowners' and Seafarers' Support of the Amendment}

The reduction and exemption of individual income tax on seafarers can effectively save the operating costs of shipowners and increase the income of seafarers to a certain extent as well as attract more people to embrace the ocean. It is expected that the proposal will be supported by both the convention of shipowners and the seafarers.

\subsection{Conformance Analysis Upon Legislative Concept of MLC 2006}

Reputed as the "Seafarers Code", MLC 2006, protects the rights and interests of seafarers in all aspects. Maritime industry is operating in an international environment, Seafarers' labor is international and restricted by the international labor market and International Shipping Regulations. Improving seafarers' income level is one of the legislative concepts of $M L C 2006$,.

In addition, Wage Guidance of B2.2.2 4 (a) of MLC 2006, stipulates "Equal Pay for Equal Work" should be applied to all seafarers employed by the same ship and shall not be discriminated against on the basis of race, colour, gender, religion, politics, national origin, or social origin. That is to say, in terms of legislation or performance, the contracting states should take it as the criterion, and different seafarers employed on the same ship should be paid the same salary if their positions and nature are identical. Given the fact that not all contracting states have tax reduction or exemption policies for seafarers at present, there are phenomena of having the same posts and income differences due to different nationalities, which is contrary to the legislative concept of "Equal Pay for Equal Work". 


\subsection{The Impact of Seafarers' Individual Tax Reduction and Exemption on China's Overall Tax Revenue}

By the end of 2019, there were 575,823 registered seafarers nationwide, including 259,466 seafarers with valid certificates of competence for international navigation vessels. There are 113,109 senior seafarers such as captains, chief engineers, chief mates, second engineers, second mates, third engineers, third mates, fourth engineer and so on. There are 146,357 ordinary oceangoing seafarers such as able seafarer deck, able seafarer engine, senior able seafarer deck, senior able seafarer engine and so on. In accordance with the table of China (Shanghai) international seafarers' compensation issued by Shanghai Shipping Exchange on March 31, 2020, the amount of individual tax paid by seafarers of different posts is estimated, and the total amount of individual tax paid by all seafarers is estimated to be about 374 million yuan. Look back on the past 2019 , the total tax revenue was 157,992 billion yuan, of which the individual income tax was 10,388 billion yuan [21]. According to the estimation in Table 3, the total amount of individual tax exemption for all oceangoing seafarers is just 374 million-yuan, accounting $0.00237 \%$ of the national tax revenue of the year and $0.036 \%$ of the national tax revenue, making very little difference to national revenue. Instead, it can enhance the professional attractiveness and happiness of being seafarers, which are key human resources in the strategy of becoming a maritime power.

Table 3. Assessment of individual tax paid by international seafarers.

\begin{tabular}{|c|c|c|c|c|c|}
\hline Duty & $\begin{array}{l}\text { Number of } \\
\text { people }\end{array}$ & $\begin{array}{l}\text { The average wage of } \\
\text { the duty }\end{array}$ & Taxable wages & $\begin{array}{l}\text { Personal tax } \\
\text { assessment }\end{array}$ & $\begin{array}{l}\text { Assessment of personal tax paid } \\
\text { by the duty group }\end{array}$ \\
\hline CAPT & 17097 & $¥ 54,763.76$ & $¥ 34,184.57$ & $¥ 6,341.14$ & $¥ 108,414,470.58$ \\
\hline $\mathrm{C} / \mathrm{O}$ & 11876 & $¥ 45,020.82$ & $¥ 28,975.05$ & $¥ 5,038.76$ & $¥ 59,840,313.76$ \\
\hline $2 / \mathrm{O}$ & 15074 & $¥ 22,145.62$ & $¥ 13,664.61$ & $¥ 1,217.92$ & $¥ 18,358,926.08$ \\
\hline $3 / \mathrm{O}$ & 15648 & $¥ 16,858.02$ & $¥ 9,596.10$ & $¥ 404.22$ & $¥ 6,325,234.56$ \\
\hline $\mathrm{C} / \mathrm{E}$ & 16826 & $¥ 52,550.26$ & $¥ 33,209.85$ & $¥ 6,097.46$ & $¥ 102,595,861.96$ \\
\hline $2 / \mathrm{E}$ & 10297 & $¥ 44,996.03$ & $¥ 28,959.10$ & $¥ 5,034.77$ & $¥ 51,843,026.69$ \\
\hline $4 / \mathrm{E}$ & 12130 & $¥ 16,840.31$ & $¥ 10,927.34$ & $¥ 439.76$ & $¥ 5,334,288.80$ \\
\hline Senior able seafarer deck & 26823 & $¥ 11,042.71$ & $¥ 7,062.27$ & $¥ 49.77$ & $¥ 1,334,980.71$ \\
\hline Able seafarer deck & 60509 & $¥ 9,516.28$ & $¥ 6,044.65$ & $¥ 20.19$ & $¥ 1,221,676.71$ \\
\hline Senior able seafarer engine & 17688 & $¥ 10,345.01$ & $¥ 6,597.14$ & $¥ 50.45$ & $¥ 892,359.60$ \\
\hline Able seafarer engine & 41337 & $¥ 9,516.28$ & $¥ 6,044.65$ & $¥ 19.44$ & $¥ 803,591.28$ \\
\hline Total & 259466 & 1 & 1 & 1 & $¥ 374,237,468.87$ \\
\hline
\end{tabular}

\section{Conclusion}

On November 20, 2019, the state council of China announced the tax reduction policy for ocean-going seafarers, which has improved the happiness and attractiveness of seafarers' career, effectively increased the supply of seafarers' labor, and contributed to the implementation of the maritime power strategy. However, the seafarers' tax reduction policy is only temporary. At the same time, the levy reduction conditions of the policy are not suitable for the occupational characteristics of seafarers who are not fixed on board and have much mobility, and there is still a gap with the prevailing practices of international shipping countries. In view of the difficulty and complexity of reducing and exempting seafarers' personal tax directly through domestic legislation, a new and feasible scheme is put forward according to Article 4, Item 9 of the Personal Tax Law: to promote the revision of $M L C 2006$, so as to definitize that the provisions concerning the individual tax reduction and exemption of seafarers are involved and help our seafarers enjoy the preferential policy of individual tax reduction and exemption in essence. At the same time, concrete procedures and specific contents of the proposal are analysed in the scheme. Finally, the feasibility of amending $M L C 2006$, is predicted in the scheme. Since the scheme is in line with the legislative concept of $M L C$ 2006, of "Equal Pay for Equal Work" and to improve seafarers' income with little impact on China's overall tax revenue, the study suggests that the amendment shall be supported by the contracting states, shipowner as well as seafarer groups. To sum up, the tax reduction and exemption scheme is reasonable and feasible.

\section{Declaration of Interests}

The authors declare that they have no competing interests.

\section{Funding}

This work was supported by the China National Office for Philosophy and Social Sciences under Grant 18VHQ004; Shanghai Planning Office of Philosophy and Social Sciences under Grant 2018EGL015.

\section{References}

[1] Xi, J. P. (2017, October 28). Deciding to Build a Well-Off Society in an All-Round Way and Win the Great Victory of Socialism with Chinese Characteristics in the New Era-Report at the 19th National Congress of the Communist Party of China. People's Daily, A01.

[2] Ministry of Transport of PRC. (2016). The Chinese Crew Development Plan (2016-2020). The Ministry of Transport of PRC. (Report No. 2016-015). 
[3] Ministry of Transport of PRC. (2016). Annual Report of Chinese Seafarers Development 2015. Dalian Maritime University Press.

[4] Maritime Safety Administration of PRC. (2012). Annual Report of Chinese Seafarers 2011. [Unpublished manuscript]. Maritime Safety Administration of PRC.

[5] Maritime Safety Administration of PRC. (2013). Annual Report of Chinese Seafarers 2012. [Unpublished manuscript]. Maritime Safety Administration of PRC.

[6] Maritime Safety Administration of PRC. (2014). Annual Report of Chinese Seafarers 2013. [Unpublished manuscript]. Maritime Safety Administration of PRC.

[7] Maritime Safety Administration of PRC. (2015). Annual Report of Chinese Seafarers 2014. Maritime Safety Administration of PRC. (Report No. 2015-001).

[8] Maritime Safety Administration of PRC. (2017). Interpretation of China Seafarers Development Report 2016. China Maritime, 2017 (07): 10-11.

[9] Ministry of Transport of PRC. (2018). Annual Report of Chinese Seafarers Development 2017. (Report No. 2018-001).

[10] Ministry of Transport of PRC. (2019). Annual Report of Chinese Seafarers Development 2018. (Report No. 2019-001).

[11] Ministry of Transport of PRC. (2020). Annual Report of Chinese Seafarers Development 2019 [Unpublished manuscript]. The Ministry of Transport of PRC.

[12] Peng, Y., Gao, D. Y, Xiao. Y. J., Wang, S. Y., \&Huang, C. H. (2014). Current situation and effect analysis of crew complaints on the way to safeguard their rights. Journal of Shanghai Maritime University, 2014, 35 (02): 58-63.
[13] Wang, Z. M., Peng, Y. \& Liu H. M., (2016), Research on Policies to Promote the Construction of China's Senior Officer Team [Unpublished manuscript], Merchant Marine College, Shanghai Maritime University.

[14] Ye, J. J., Wu, Y., Chen, F. H., \&Wang, Y. Q., (2017), Will Individual Income Tax Cut Increase Labor Supply? Management World, 2017 (12): 20-32+187.

[15] MA, N. Y. (2019), Thailand Personal Income Tax Deduction System and Its Enlightenment. International Taxation, 2019 (03): 50-54.

[16] HUANG, G. L. (2008). Discussion on the Functional Orientation of Individual Income Tax in China. Journal of Guizhou Normal University (Social Science Edition), 2008 (03): 68-73.

[17] Yang, Z. Y. (2018). Construction of Modern Taxation System: Reflections on the Development of Individual Income Tax in the Last 40 Years. Economic Vertical and Horizontal, 2018 (06): $51-59+2$.

[18] Wang, Y., Tian, Z. W., \&Wang Z. T. (2019). Study on Income Redistribution Effect of Individual Income Tax Reform in 2018. Collected Essays on Finance and Economics, 2019 (08): 31-38.

[19] Sheng, C. Y., Gao L., Xing H. Y., \&Hou M. (2019). Analysis of the Causes of Personal Income Tax Reform and Domestic Path Choice. Value Engineering, 2019, 38 (27): 54-55.

[20] HUANG, Y. T. (2013). Study on International Maritime Labour Convention [Master's thesis, Fudan University].

[21] China Treasury Department of the Ministry of Finance: Financial Revenue and Expenditure 2019, 10 February 2020, http://gks.mof.gov.cn/tongjishuju/202002/t20200210_3467695 .htm. 